\title{
Russian healthcare in the development of medical tourism
}

\author{
Natalia Sedova ${ }^{1}$, Larisa Minasyan ${ }^{1,2}$, Gennady Shchekin ${ }^{1}$, Georgy Tabatadze ${ }^{1}$, and Olga \\ Kostenko $^{1}$ \\ ${ }^{1}$ The Volgograd State Medical University, 1, Pavshikh Bortsov, 400131, Volgograd, Russia \\ ${ }^{2}$ Don State Technical University, 1, Gagarina sq., 344003, Rostov-on-Don, Russia
}

\begin{abstract}
The authors consider the possibilities of national health care in the context of the export of medical services. The methodology of the work is based on an approach based on different specifics of medical and healthcare tourism and their correlation. The forms of state support are described in the article. The assessment of the plan for the development of the export of medical services and the ways of its implementation are given. The following pointes are highlighted: trends in the commercialization of medical tourism, business strategy, social, economic and technological risks in the development of medical tourism, and the prospects of development. The most attractive areas of medical care in Russia for foreigners are explicated. The financial benefits of exporting medical services and the issue of Russia's international cooperation in this area are considered.. It is done for a comparative analysis of the achievements in different countries in the medical and tourism industry. The forms of cooperation with the Joint Commission International (JCI) in promoting the export of medical services in Russia were noted. The article also deals with the problems and barriers to the development of the export of medical services and possible ways to solve them.
\end{abstract}

\section{Introduction}

Medical tourism is a type of tourist activity in which the goal is to provide medical care, implemented by means of a tourist service [1]. At the same time, the definition is interpreted differently in Russian and English-language literature. Russian scientists propose to differentiate between medical and healthcare tourism, while in the Western literature there is only one concept - medical tourism. Russian authors understand medical tourism as the treatment of a specific disease in a hospital, as for healthcare tourism, it is called recreational and rehabilitation tourism, often, it is a sanatorium-resort treatment.

To conduct a correct comparative analysis, an unambiguous interpretation of the terms is necessary, so in this study, the term "medical tourism" is used in the English-language interpretation.

\footnotetext{
${ }^{1}$ Corresponding author: larmin1@mail.ru
} 
Medical tourism is a new social phenomenon that requires careful study not only in the applied sense, as it is being done now, but also in methodological terms, since its "spontaneous integration" into the system of social institutions can have negative consequences. The theory of medical tourism can be built on the basis of philosophical, sociological, ethical, legal, economic and surely medical research in this area. Now we have accumulated enough experience of such research to be able to generalize and conceptualize it.

Conceptualization of medical tourism is a complex task, the solution of which involves the following steps:

1. Definition of the concept "medical tourism" and explication of its connection, in terms content, with related concepts ("tourism", "medicine", "health tourism", "healthcare tourism"").

2. Definition of the object and subject of medical tourism as a specific sphere of social and medical activity.

3. Finding out the status of medical tourism in a) medicine as a social institution and b) tourism, which can also be interpreted as a social institution.

4. Definition of the functions and methods in medical tourism.

5. Formulation of the genesis laws in medical tourism.

6. Forecast for the development of medical tourism.

We do not aim to give an exhaustive description of each of these steps, but we consider it is necessary to systematize the information that is already available on the last two points. They are directly related to the social measures that will allow us to unlock the potential of Russian healthcare in the development of medical tourism. At the same time, depending on the degree of study of a particular issue, it will be either a description, an explanation, or a prediction-according to the principles of the methodology.

\section{Materials and method}

The definition of the basic concepts of medical tourism was given in the monograph of professors G. Y. Shchekin and N. N. Sedova "Medical tourism is a type of tourist activity in which the goal is to provide medical care, implemented by means of a tourist service" [2, 222]. There was also a definition of medical tourism, which we singled out to a separate subinstitute:"Healthcare tourism is a subsystem of tourism activity, which implements the functions of recreation and rehabilitation $[2,124]$. The authors stated in this work that the organization of healthcare tourism in our country appears as a system of sanatorium-resort associations, travel companies and consumers of medical tourism services, focusing on the expansion of the recreational function of this system to the detriment of rehabilitation.

Now it is possible to develop this approach by defining the ratio of medical and healthcare tourism. Indeed, medical interference in the form of clinical manipulations are used in the sanatorium and spa practice now quite successfully. However, most often, such services are provided for an additional fee. Information about this is available on the website of any sanatorium.

Many health resorts (sanatoriums) provide psychotherapist services, dental services, including prosthetics. They are also not included in the price of the tour.

On the other hand, hospitals that perform complicated surgeries and implement treatment programs of serious diseases offer rehabilitation services [3-5]. Thus, there is no hard border between medical and healthcare tourism. However, both are included in the health tourism system, although it includes other components.

For example, recently you can find such formulations as "balneological tourism", "mountain tourism", etc. Obviously, these types of health tourism include both organized and 
individual methods of recreation and rehabilitation, but not treatment, since medical intervention always involves strict organization and control.

\section{Results}

\subsection{The trend of commercialization of medical tourism}

Medical tourism is one of the most profitable types of modern tourism, which determines the economy of a huge number of countries all over the world. The global medical tourism sector has one of the highest rates of growth and development; more than fifty countries indicate this direction as one of the goals of national policies that contribute to the emergence of a new concept of health $[6,7,8]$. According to this concept, if a person cannot get the necessary medical care in the country of permanent residence, he can apply for this help in another country, as well as independently choose a hospital and / or attending doctor offering the necessary medical services $[9,10]$. The emergence of this phenomenon was facilitated, on the one hand, by globalization, the integration of European countries, the expansion of the EU, the simplification of the migration of tourist resources, and, on the other, by the increase in health care costs, which has been observed for several years. Nowadays, a global market for medical services has already been formed with its own infrastructure (medical management, accreditation bodies, medical tourism agencies and tour operators, specialists in the field of medical travel).

There are many reasons for travelling to another country for treatment. At the same time, the main reason is - to save money and time. For developed countries of Europe and America, travelling with medical purposes is the desire to save on simple types of treatment (in the USA, for example, the most expensive medicine in the world); preventive and healthimproving trips to resorts, which have no similarity in medical tourist's native country (for example, mineral waters of the Czech Republic, the Dead Sea in Israel); unwillingness to wait in queues in your own country (it is better for a British or Canadian to pay a mutually advantageous price to a medical professional in Eastern Europe than to wait six months for a free one at the place of residence). For residents of those countries where medicine is less effective than in developed countries, medical tours abroad are a forced measure. There are several reasons for this: unprofessionalism of doctors (not always through the fault of the doctors themselves); the authorities' indifference to the state of health care in the country; inability to wait for surgery because of health reasons; lack of modern equipment and necessary medicines; inability to provide proper care and rehabilitation period (important for severe diseases like cancer); inability to make an accurate diagnosis. Other advantages of medical tourism will be: treatment under the personal supervision of professors and doctors; the choice of a medical institution is made independently by the patient (it should be noted that this can be not only a public, but also a private clinic, and the choice itself will depend on the personal preferences and financial capabilities of the patient); extraordinary consultations of leading specialists in any medical specialty; special professional, full-fledged medical care for patients (this is first of all for patients who have undergone surgery, are limited in the ability to move and need proper care) and, most importantly, there are huge opportunities to rehabilitate and improve the quality of life of patients suffering from diseases that cannot be completely cured [2].

According to the International Association of Medical Tourism, about 11 million tourists travel for medical care every year. According to the medical tourism index of the International Health Research Center, the commercial medical services sector will reach a turnover of 3 
trillion US dollars by 2025 , and at the moment this market is estimated at 439 billion US dollars [11].

\subsection{Business strategy for the development of medical tourism in Russia}

Realizing the importance of the development of medical tourism for the national health care and the economy of the country, President of the Russian Federation Vladimir Putin gave an order to the government to increase the export of medical services by four times by 2024, bringing the volume of this market to one billion US dollars. The order was given within the framework of the Presidential Decree "On National goals and strategic objectives of the development of the Russian Federation for the period up to 2024" dated May 7, 2018, No. 204 [12]. The federal project "Development of health services exports" is part of the national project "Health" [13]. The project is designed for the period from 2019 to 2024, which will involve federal medical centers and 71 regions of the country with all medical institutions. The amount of investment in support of the project, according to the head of the coordinating center for its implementation at the Central Research Institute of Healthcare Organization and Informatization, Sabina Green, will amount to 30 million rubles per year [14].

This support is due to the fact that low awareness of foreign citizens about the possibilities of obtaining medical services in the territory of the Russian Federation hinders the implementation of the project. Active assistance will be provided by the Ministry of Economic Development of the Russian Federation, which will be responsible for the export of services in general. In addition, the portal was launched "russiamedtravel.ru" the main goal of which is to promote Russian medical institutions abroad. Indeed, according to the Russian Association of Medical Tourism (AOMMT), since 2016, in Russia, there is an increase not only in domestic medical tourism, but also in inbound tourism. This means that in the nearest future, the actions of the authorities will be aimed at strengthening the support of the initiatives put forward by state and commercial medical centers, which will create conditions for the establishment of the export of medical services. To achieve the intended results, it is necessary not only to create an adequate legislative framework for the development of this area, but also to improve the state of medical and preventive institutions that can accept foreign patients.

However, you can look at the proposals and requirements put forward in two ways. On the one hand, modern Russia has a rich history and traditions, which are combined with the latest medical technologies that are widely implemented in medical organizations. In the Russian Federation, high-quality medical care is provided in a wide range of nosology. Other reasons that encourage foreigners to be treated in our country are the following: highly qualified doctors; chances of receiving high-quality care; the possibility of accurate diagnosis and effective treatment; the possibility of an individual approach to the patient; a wide range of available medical services [15]. The most attractive areas of medical care for foreign patients are: dentistry $44 \%$, gynecology and urology $24 \%$, ophthalmology $10 \%$, plastic surgery $10 \%$, cardiology $5 \%$ and, others, cosmetology, orthopedics, oncology, infertility treatment and rehabilitation [16,17].

According to the Ministry of Health of the Russian Federation, at the end of 2016, 66 thousand patients turned to the services of Russian medical institutions, and in 2017 their number was more than 110 thousand foreign citizens. Hospital care accounted for 74 per cent of the financial income from the export of health services [11], so in 2017, medical institutions earned about $\$ 250$ million [18]. It is worth noting that patients from the following countries and regions most often come to Russia as medical tourists: Commonwealths of Independent States, South east Asia (The People's Republic of China, North Korea, Socialist Republic of Vietnam), Middle East (State of Israel, Kingdom of Bahrain), Europe (Federal Republic of Germany, Baltic countries, Scandinavia) and others. 
On the other hand, the Federal Project "Development of Medical Service Exports" started at relatively low positions. It should be taken into account that modern medical tourism is not only the availability of good specialists and modern medical equipment, that allow to compete successfully in the medical services market, but a complex system of interconnection of medicine, service, infrastructure, insurance organizations and logistics. Unfortunately, this process of interconnection is not established in the country. For reference, according to the Medical Tourism Index, the Russian Federation ranks 41-st in terms of exports of medical services in the ranking of 46 countries (Table 1) [19].

Table 1.2020-2021 MTI Overall Ranking.

\begin{tabular}{|c|c|}
\hline 1. Canada & 76.47 \\
\hline 2. Singapore & 76.43 \\
\hline 3. Japan & 74.23 \\
\hline 4. Spain & 72.93 \\
\hline 5. United Kingdom & 71.92 \\
\hline 6. Dubai & 71.85 \\
\hline 7. Costa Rica & 71.73 \\
\hline 8. Israel & 70.78 \\
\hline 9. Abu Dhabi & 70.26 \\
\hline 10. India & 69.80 \\
\hline 11. France & 69.61 \\
\hline 12. Germany & 69.29 \\
\hline 13. Oman & 69.03 \\
\hline 14. South Korea & 68.81 \\
\hline 15. Czech Republic & 68.32 \\
\hline 16. Taiwan & 67.93 \\
\hline 17. Thailand & 66.83 \\
\hline 18. Italy & 66.75 \\
\hline 19. Dominican Republic & 66.32 \\
\hline 20. Argentina & 66.26 \\
\hline 21. Portugal & 65.96 \\
\hline 22. South Africa & 65.82 \\
\hline 23. Hungary & 65.69 \\
\hline 24. Philippines & 64.99 \\
\hline 25. Colombia & 64.95 \\
\hline 26. Egypt & 64.81 \\
\hline 27. Malta & 64.75 \\
\hline 28. Brazil & 64.35 \\
\hline 29. Poland & 64.10 \\
\hline 30. Turkey & 63.91 \\
\hline 31. Morocco & 63.80 \\
\hline 32. Bahrain & 63.65 \\
\hline 33. China & 63.47 \\
\hline 34. Greece & 63.45 \\
\hline 35. Saudi Arabia & 63.32 \\
\hline 36. Jordan & 63.26 \\
\hline 37. Panama & 62.77 \\
\hline 38. Tunisia & 61.78 \\
\hline 39. Qatar & 61.13 \\
\hline 40. Jamaica & 60.74 \\
\hline 41. Russia & 60.17 \\
\hline 42. Mexico & 59.47 \\
\hline 43. Lebanon & 57.14 \\
\hline 44. Guatemala & 55.04 \\
\hline 45. Kuwait & 54.84 \\
\hline 46. Iran & 44.38 \\
\hline
\end{tabular}

Our country loses both in volume and in attractiveness of the industry. According to the index of medical tourism, the state of health care in the Russian Federation is estimated as low. We are forced to give way to countries such as Singapore (2-nd place), India (10-th place), Turkey (30-th place), Jordan (36-th place) and many others.

Another international organization whose actions are aimed at helping health institutions, Ministries of Public Health and other interested organizations to improve the quality and 
safety of patient care is the Joint Commission International (JCI). It is the largest and oldest medical accredited organization in the world and operates in more than 90 countries.

To earn and maintain the Gold Sealof Approval, that is, accreditation that confirms the continuous compliance of the quality of medical care and patient safety with internationally recognized standards, the organization has to pass the quality management accreditation system of medical care, which is conducted by JCI experts every three years, laboratories every two years [18]. It should be noted that to date, only 656 medical institutions in the world have received this accreditation, while less than $5 \%$ of applicants can prove that they are worthy of it.

The number of medical institutions accredited by the JCI in our country at the end of 2018 was only 2 , by the beginning of 2019 , their number increased to 4 . Thus, in Russia there are international-level clinics (hospitals) with an absolute guarantee of trust and the highest reputation in the medical world. But there aren't many of them. For example, the Republic of Singapore has 23 hospitals accredited by the JCI, whose services cost $35 \%$ less than in the United States. In Spain, 23 organizations have JCI accreditation and only 8 of them are hospitals. The benefits of JCI accreditation are obvious, as in JCI-certified clinics (hospitals), all processes are primarily focused around the interests and safety of patients. It is not by chance that the largest international insurance companies recommend their clients to contact the clinics accredited by JCI. It should be noted that JCI accreditation helps to increase the profits of medical organizations. For example, the accredited hospital in China increased its income five-fold from 2005 to 2017, a hospital in Spain saved more than \$ 12 million and as a result, the hospitalization procedure has been adjusted and paperwork has been reduced.

\section{Discussion}

\subsection{Social, economic and technological risks in the development of medical tourism}

The main problems and barriers to the development of the export of medical services in our country are: the need for financial assistance to health care providers (for example, related to covering the costs of international accreditation, certification, participation in foreign exhibitions), consulting services, assistance in advertising and promoting relevant services abroad; language barriers; poor infrastructure to attract medical tourists; administrative barriers related to the difficulty of obtaining a visa to enter Russia for medical treatment; outdated material and technical base of the sanatorium and resort fund.

The action plan for the implementation of the "Strategy for the Development of service export until 2025" assumes the possibility of increasing the export of medical services in the Russian Federation by solving the following tasks: overcoming language barriers, in particular those related to receiving services in a foreign language and training medical staff; providing financial assistance to medical service exporters, including reimbursement of international accreditation and certification costs; digitalization of the medical sector related to the digitization of medical records; development of telemedicine; promotion of Russian medical service providers and their products abroad; updating an outdated health resort fund; overcoming administrative barriers related to obtaining visas for medical purposes; solving the issue of cross-border health insurance [11]. Time will tell how far these plans are destined to be implemented.

Based on the above, we can assume that the development of medical tourism will be mainly associated with the introduction of new biotechnologies into medical practice. They will be the main value in gaining health. Now there is a lot of talk about the problems of 
introducing new biotechnologies, in particular, "human enhancement" technologies in medical tourism [20,21]. However, little is said about the problems that will need to be addressed in this regard. We will focus only on one issue related to the adoption of a new Federal law in the Russian Federation that is directly related to this problem. On June 8, 2016, the State Duma adopted and on June 15, 2016, the Federation Council approved Federal Law No. 180-FL "On Biomedical Cell Products" of June 23, 2016. It is obvious that cellular technologies in medicine make it possible to make a breakthrough in the treatment of a number of serious diseases and, consequently, the world's leading clinics (hospitals) are widely implementing them in practice. The new law very clearly and in detail regulates all operations with cellular products on the territory of the Russian Federation. It is important to note that products registered abroad must be re-checked and registered in Russia before using them. This is stated in Article 8 "State registration of biomedical cell products":

"1. Production, sale, use, storage, transportation, import into the Russian Federation, export from the Russian Federation, destruction of biomedical cell products are carried out if they are registered by the authorized federal executive authority."

Nevertheless, the law does not say anything about the risks of patients seeking medical care, including the use of biomedical cell products, in clinics (hospitals) in other countries. If the product is not registered in Russia, and the patient needs appropriate therapy, then he goes to the country where this product is used legally. So, the norm given in the article loses its meaning. In addition, the effects of the use of allogeneic biomedical cell products in a heterogeneous ethnic environment have not yet been studied to the extent that would ensure complete safety of such use. The same can be said about combined biomedical cell products. This is one example of the risks that can arise from the uncontrolled development of medical tourism. But can it be controlled at all? It is unlikely that this is possible, for example, in the domestic health care. However, it is necessary to strive for this, since "spontaneous" medical tourism can bring more negative effects than positive ones. Here, the competition between clinics and tour operators mentioned above seems very promising. This competition is a form of control, so it is in the interests of any state to support its participants.

\subsection{Prospects for the development of medical tourism}

Thinking about the patterns of medical tourism development will be somewhat premature, since they are not clearly visible. But some assumptions about this can be made already now.

First. The regularity of medical tourism development can be considered competition in the provision of tourist services between travel agencies and clinics (hospitals), where special units are created [22].

Second. The flows of inbound and outbound tourism will always be inversely correlated: the more people will leave the country for treatment abroad, the fewer will come to this country for treatment. And vice versa. This is obvious, since the presence of highly effective clinics in a particular state involves providing medical care to its citizens in full, therefore, they do not need to go anywhere. At the same time, this factor attracts foreign patients.

The third. The development of domestic medical tourism in any country will be directly related to its socio-economic situation: the worse it is, the more actively domestic tourism will develop in comparison with outbound tourism. This is obvious, since high-tech medical services are expensive, and the cost of moving, living and service within the country is lower than when traveling abroad.

Fourth. It can be assumed that the regulation of prices for medical tourism services will not be subject to the laws of the development of the market economy (if there are any), since health is an exceptional value: the cost of returning health and, moreover, saving from death is 
always lower than the personal value of health and life. As for the patterns of development some certain areas in medical tourism, they are unlikely to exist, because there are too many variables: the epidemiological situation, climate change, the impact of industrial production, information flows, urbanization, the emergence of new biotechnologies, and so on. It is not possible to derive some formula of these variables.

\section{Conclusion}

1. Medical tourism is a sphere of modern healthcare and hospitality, both in the world and in the domestic market of medical services, a factor in the development of international communication, contributing to the integration of markets with a developed infrastructure into a single system. It includes not only medical institutions, advanced equipment and highly qualified specialists, but also such business sectors as banking, legal support, insurance, transport, communications, etc.

2. Medical tourism is becoming not only popular in the social life of society, but also a competitive type of economic activity of the state. Considering the medical practice of countries where medical tourism has a long history and is represented by an established industry, we can talk about the possibility of borrowing the accumulated experience in order to create a national flexible system. At the same time, it requires a critical understanding of these borrowings, their analysis and adaptation to national realities.

3. Considering the capacity of the national health programs for medical tourism, organized in the framework of the decree of the President of the Russian Federation "On the national goals and strategic objectives development of the Russian Federation for the period up to 2024” from May 7, 2018 № 204 and Federal project "Development of export of medical services," it can be argued that in the coming years, the authorities' actions will be aimed at strengthening the support of initiatives of state and commercial medical centers. This will create a condition for the promotion of medical tourism services, and thus strengthen the prestige and competitiveness of the national health service in the international market of medical services. At the same time, in order to achieve the intended results, it is necessary not only to create an adequate legislative framework, but also to improve the condition of medical institutions capable of receiving foreign patients.

4. Today's planned growth of medical tourism in the framework of development of export medical services program, certainly, helps revitalize the market, increase competition, and, as a consequence, to improve the quality of medical care. Optimization of medical tourism is possible under the condition of centralized control of the Ministry of Health of the Russian Federation on the basis of regular sociological monitoring of the quality and distribution of medical tourism services in the country.

\section{References}

1. N.Sedova, G.Shchekin, Medical tourism: history, theory, practice, Volgograd, 304 (2017)

2. N.Sedova, G.Shchekin, Medical tourism: history, theory, practice, Volgograd, 276 (2014)

3. Modern tourism in medical and health care activities, Volgograd, 124 (2016)

4. M.Subasinghe, D.Magalage, N.Amadoru, et al., 11th Annual IEEE Information Technology, Electronics and Mobile Communication Conference, IEMCON 2020, 314319 (2020) doi: 10.1109/IEMCON51383.2020.9284898 
5. M. Osadchuk, M.Trushin, A.Osadchuk, et al., Journal of Environmental Management and Tourism, 11(7), 1871-1876 (2020) doi 10.14505//jemt.v11.7(47).25

6. Y.H.Chen, T.Chang, Advances in Science, Technology and Engineering Systems, 5(6), 1690-1697 (2020) doi: 10.25046/aj0506201

7. R.Pagan, D.Horsfall, Sustainability (Switzerland), 12(21), 1-17 (2020) doi: $10.3390 /$ su12218818

8. T. Lee, H.Lim, D.Kim, International Journal of Tourism Research, 22(6), 693-710 (2020) doi: $10.1002 /$ jtr.2366

9. H.Azimi, Journal of Environmental Management and Tourism, 11(8), 1893-1901 (2020) doi: 10.14505/jemt.v11.8(48).01

10. O. Krestyaninova, Technical and technological problems of the service, 3(49), 66-69 (2019)

11. The decree of the RF Government from 14.08.2019 N1797-r (edition of 23.11.2020) $<$ On approval of the Strategy of development of export services 2025> (along with the "Plan of measures on realization of Strategy of development of service exports by 2025"), URL: http://www.consultant.ru/cons/cgi/online, (accessed 28.04.2020)

12. Decree of the President of the Russian Federation "On national goals and strategic objectives of the development of the Russian Federation for the period up to 2024" dated May 7, 2018 No. 204, URL: https://base.garant.ru/71937200/\#friends, (accessed 28.04.2020)

13. Federal project "Development of export of medical services", URL: https://russiamedtravel.ru/ru/meditsina-v-rossii, (accessed 19.04.2020)

14. Russia as a medical brand, Kommersant, URL: https://www.kommersant.ru/doc/4197412, (accessed 20.04.2020)

15. G.Shchekin, T.Guba, Asian Social Science, 11(7), 233-239 (2015) doi:10.5539/ass.v11n7p233

16. A. Nenarokomov, N. Orudjiev, T.Antonova, et al., Bioethics, 1(9), 36-51 (2012)

17. O.Nikitina, The Eurasian Scientific Journal, 5(10), 38 (2018)

18. Joint commission international Certification, URL: https://www.xanitmedicaltourism.com/ru/who-we-are/joint-commission-internationalcertification, (accessed: 19.04.2020)

19. Medical Tourism Index 2020-2021, URL: https://www.medicaltourism.com/mti/home, (accessed 20.01.2021)

20. N.Sedova, B.Navrotsky, Modern tourism in medical and health care activities, Volgograd, 23-28 (2016)

21. A.Thacoor, P.V. Den Bosch, M. Akhavani, Aesthetic Surgery Journal, 39 (7), 786-791 (2019) doi: 10.1093/asj/sjy338

22. D.A. Gârdan, I. Dumitru, I.P. Gârdan, et al., Sustainability (Switzerland), 12 (21), 1-18 (2020) doi: 10.3390/su12219191 